\title{
Usage of Miniature Houses Built using Construction Materials in Engineering Educational Corporate Social Responsibility (CSR) Programs
}

\author{
Kevin Effendy ${ }^{1, a}$, Tanti Octavia ${ }^{2, b}$, Gunawan Budi Wijaya ${ }^{3, c}$ \\ 1,2,3 Petra Christian University, Jl. Siwalankerto 121-131, Surabaya 60236, Indonesia \\ ay71200013@alumni.petra.ac.id, b tanti@petra.ac.id, c gunawanbw@petra.ac.id
}

\begin{abstract}
The demand for engineers in Indonesia has not been met with the number of professional engineers working in their respective fields. This is partly due to the low interest in engineering among students. Therefore, various programs are implemented by the government and companies to be able to introduce, educate and change perceptions on the field of engineering. This research was conducted to propose a Corporate Social Responsibility (CSR) program in order to meet these objectives. The proposed program is an educational program in the form of a workshop on residential construction using miniature houses built of real construction materials as demonstration and learning tools. The program is aimed at high school students in accordance with the goal of increasing public interests and the number of potential engineers, particularly in the field of civil engineering. The validation process of the proposed program is done by distributing questionnaires to construction companies and high school students as stakeholders in the program's execution. The validation results show that the proposed program is quite attractive to construction companies and high school students, including those who are not interested in the engineering field. The program is also deemed feasible and able to meet the goal of developing students' interest in engineering.
\end{abstract}

Keywords: Corporate social responsibility (CSR), education, engineer, miniature house.

\section{Introduction}

In this time leading up to the era of Industry 4.0 and the ASEAN Economic Community (AEC), the need for engineers for Indonesia's development has not been met by the number of professional engineers. According to the General Secretary of Institution of Engineers Indonesia (Secretary-General Professional Engineer Program/PII), the number of engineers in Indonesia as of January 2019 is only around 800 thousand, while the ideal number is 200 engineers for every 1,000 residents [1]. According to him, the low number of engineers in Indonesia is caused by the image of engineers being rigid and serious figures, making the younger generation reluctant to become one.

In addition, the Minister of National Development Planning (PPN) / Head of the National Development Planning Institution (Bappenas) said that the number of engineering graduates working as professional engineers is much less, only around 5 thousand out of 600-700 thousand graduates [2]. Contrary to that fact, professional engineers in their respective fields are really needed. Consequently, the government aims to increase the number of professional engineers, one of which is through the implementation of the Professional Engineer Program (PPI) by universities [3].

According to UU No. 11 Year 2014 on Engineering, a part of the government's programs in developing engineers is done through socialization and education to attract the younger generation to the fields of science, technology, and engineering [4]. In accordance with that, a part of an engineer's responsibility is to be involved in the said educational process to increase the number of Indonesian professional engineers. To achieve this goal, various Corporate Social Responsibility (CSR) programs have been carried out by various engineering companies. PT. Tripatra Engineers and Constructors organized an Engineering Camp to introduce the fields of Science, Technology, Engineering and Mathematics (STEM) to junior high school students [5]. In recent years, several studies related to engineering education through CSR programs have also been developed. Smith and Lucena conducted a survey to track changes in the students' knowledge, attitudes and skills about CSR and its relations to engineering [6].

To educate and attract the younger generation to the field of civil engineering, this study aimed to plan an interactive program as an educational tool. A method to learn civil engineering has previously been utilized through experiential learning activities on construction sites and experimental testing of reinforced concrete beam specimens in laboratories [7]. However, since this study only used reinforced concrete beam specimens as learning objects, it did not comprehensively describe and emulate the scope of civil engineering works.

By learning from previous educational and engineeringrelated CSR programs, as well as innovations on construction models, a modified educational program was arranged. The proposed CSR program in this study is a residential construction workshop using miniature houses built of real building materials as demonstrative tools which provides an interesting learning experience, as well as a representative visual of the work done in the field of civil engineering. The program was proposed to be conducted by companies in the field of civil engineering as part of engineering education for community members, especially students, to increase the number of Indonesian professional engineers.

\section{Literature Studies}

\subsection{Best Practices of Community Service Programs}

Literature studies were conducted to learn the best practices of community service programs in the field of civil engineering, especially those involving education and application of the science. Community service programs can be categorized into three groups based on the concept of the 
program being implemented, namely educational programs, project-based programs and the combination of both educational and project-based programs.

\subsubsection{Educational Community Service Programs}

The first category of community service programs is education for community members, generally children and students. The objectives of the programs include introducing or teaching STEM (science, technology, engineering, math) as the basis of other engineering fields. This type of program is the most commonly implemented.

One of the programs was conducted by the engineering faculty of the University of Pretoria in South Africa, starting in 2005 [8]. The program was intended to have an impact on society as well as increase student awareness of their responsibilities to society. One of the most common activities was teaching students or other community members. Lessons provided by students in the program include mathematics, science and computer technology which are the basics of engineering. Teaching basic sciences benefited students in developing soft skills of management and program planning. In addition, students were also able to contribute to the improvement of basic education in several schools.

Another variety of this type of program are competitions, workshops or similar activities which aim to introduce science and increase students' interest in engineering. One of them was implemented in South Tangerang, Indonesia, in 2019 by PT Tripatra Engineers and Constructors, a company working in the field of engineering, procurement and construction (EPC). The TRIPATRA Engineering Camp was implemented as a form of corporate social responsibility (CSR), which supported government programs in improving human resources [5].

The President Director of TRIPATRA said that the engineering camp was aimed to introduce STEM and the world of engineering to junior high school students and foster their interest in engineering [5]. This program was conducted for three days and was participated by 50 students. The students were provided materials on engineering theories and practices, starting from the basic sciences of STEM up to their applications in the forms of experiments, such as coding robots and making solar panels. The hope of TRIPATRA, was that this program was able to add value to all stakeholders as well as contribute to the development and improvement of human resources in Indonesia [5].

\subsubsection{Project-based Community Service Programs}

Other community service programs are project-based. This type of program is very commonly implemented in the form of service learning by various engineering programs at universities in the United States. One of them is the EPICS (Engineering Projects in Community Service) program initiated by Purdue University's electrical and computer engineering program in 1995 [9]. The program's main objective was focused on providing practical experience and opportunities to train students in soft skills of communication and collaboration, plus contributing to society by solving problems using engineering. Each project involved collaboration among fellow engineering students from multiple fields with social institutions or non-profit organizations.

One of the civil engineering EPICS programs was implemented by Purdue University in 1996 in the form of designing cost and energy-efficient home constructions [9]. In executing the program, the university collaborated with the Greater Lafayette Affiliate of Habitat for Humanity which was involved in the construction of affordable housing for lower economic classes.

A similar program executed by the Illinois Institute of Technology, Engineering Without Borders, started in 2005 with a project in Haiti [10]. The program's projects were carried out by students from various engineering programs together with local Non-Government Organizations (NGOs). Projects done include the installation of a solar-powered electrical system and a water distribution system.

Both participating students and partnering organizations view that the programs were advantageous. Students were benefited from gaining both technical, practical knowledge and soft skills. Meanwhile, partnering organizations of the programs benefited from the completed projects which can be of use to the community.

\subsubsection{Educational Project-based Community Service Programs}

The last type of community service program combines concepts from previous ones. This type of program is projectbased, but it involves community members in the project as well. The program also provides training or workshops on the project to be done and related engineering sciences. Apart from contributing to society, another goal of the program is to increase society's interest and competence in STEM. Some programs target specific groups of people, especially elementary and middle school students.

This type of program was implemented by Farinde, Tempest and Merriweather in 2014, in the United States [11]. The program called Bridge to Engineering was planned as an ISE (Informal Science Education) for underrepresented high school students with engineering students as mentors [11]. In addition to a general presentation on engineering, students were also equipped with engineering theories and practices related to the project being worked on. The students were then actively involved in constructing the project.

The project in this program was the construction of a solarpowered irrigation system that distributed collected rainwater. Construction of the project's components involved the application of several fields of engineering. The planning of piping and pumping systems involved mechanical engineering, the rainwater collection system involved civil engineering and the solar power system involved electrical engineering.

Another program was implemented by Goodyer and Soysa in 2017 in New Zealand [11]. This program, called Hello Café, specifically targeted 10-13-year-old female students [11]. Although the aim of the program was engineering education, the aspects of community service were also emphasized to the participants. Engineering was introduced through the process of solving problems and working on projects based on the community's needs. The program consisted of 10 types of workshops, each planned with different materials of theories and applications.

One of the materials for the workshop was the usage of wind turbines as a renewable energy source. This material was one which introduced the concept of sustainability in engineering. There were also materials related to civil engineering, such as the design and construction of flood resistant houses. 
Based on the responses of the participants, it was concluded that the programs implemented were able to increase students' interest and understanding of science and engineering. The participants' responses also proved that this program was able to show that learning and practicing engineering can be exciting instead of boring.

\subsection{Miniature house Built using Construction Materials}

One of the learning tools proposed for the educational CSR program in this study is a miniature house made from real construction materials. The construction of these miniature houses was first demonstrated and popularized through a YouTube channel by Frank Perez, the founding architect of Ouroboros Arq, an architectural and construction company from Bogota, Colombia [13].

In the demonstration by Ouroboros Arq, a 1:10 scale miniature house was made similar to any architectural model or miniature, but with materials and construction methods used in real buildings (Figure 1) [13]. To Frank Perez, the aspect of reality in terms of construction was very important for the demonstration to really represent the actual construction of a house [13].

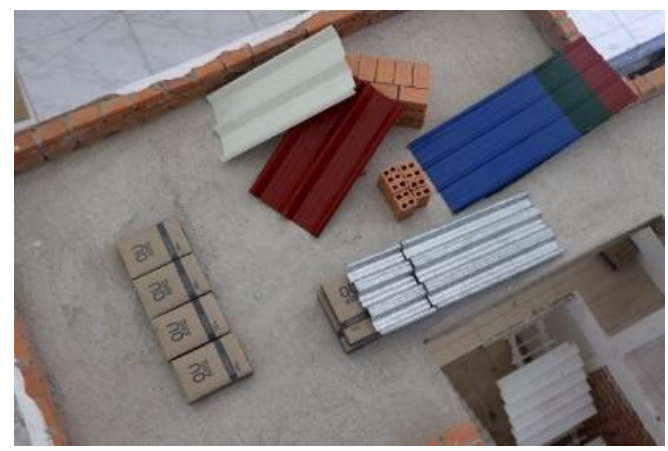

(a)

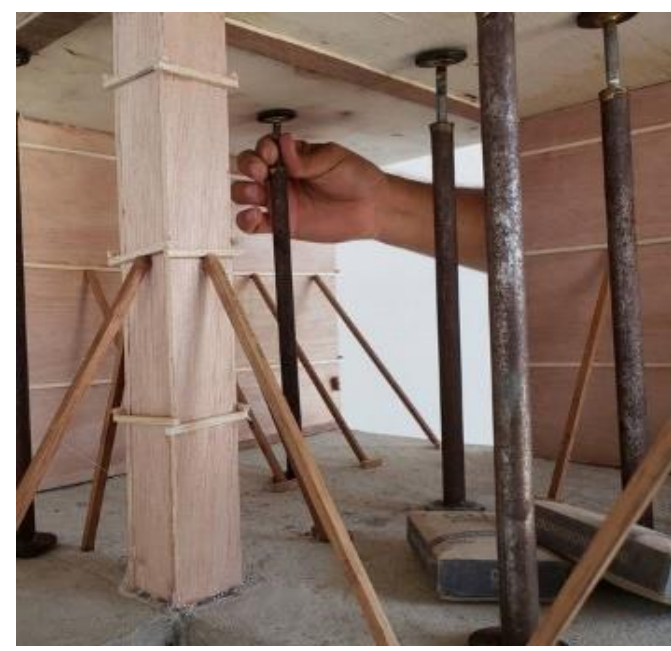

(b)

Figure 1. (a) Construction Materials Used [13] and (b) Construction Process of the Miniature House by Ouroboros Arq [13]

Construction of the miniature house began with "land" preparations, which were the work areas along with their boundary lines and grids, followed by excavating the soil for its foundation. Concrete reinforcing was done using smalldiameter rebars or iron wires. Concrete casting was done using cement, sand, fine gravel and water to make concrete. Concrete reinforcing and casting were done from the foundations to the superstructures, then were proceeded with the construction of walls, floors and finishes which also use real miniature-sized bricks and tiles. According to Frank, the construction of the entire model could take 2-3 months due to the complicated execution process [13].

Although demonstrations of the making of miniature houses have often been done and are increasingly being practiced, their usage as learning tools is still rare. Frank said that since this trend was still relatively new, there was still room for development so that this activity would not merely be a trend [13]. Having a demonstration item which is quite representative to its original condition, hopefully, it could be a relevant learning tool for engineering practices, one of which is in the construction of individual houses.

\section{Methodology}

This research was conducted through literature studies on community service-based programs related to engineering. Community service programs were analyzed to learn about the objectives, target audiences and ideas or concepts that underlie the programs. The results of the program analysis were then compared to the objectives of this study, namely the design of an education-based program to increase public interests, improve perceptions and knowledge on the field of engineering. Ideas in line with the research objectives were then collected and adopted to formulate a new educational CSR program to be proposed.

Main sources of inspiration and reference to propose a workshop program with interactive elements and activities were obtained from previous CSR educational programs, especially those which are project-based. Programs such as those conducted by Farinde, Tempest and Merriweather [11], and by Goodyer and Soysa [11] came in the form of workshops to present information, followed by projects related to them. The formulation of the workshop sessions and sequence referred to the demonstration by Ouroboros Arq [13], which also inspired the usage of miniature houses built using real construction materials as learning tools. The sessions were based on the procedures and types of work involved in building the miniature house, which followed general construction work practices. The works were categorized, grouped and then composed into sessions of interactive learning on the construction processes.

The proposed workshop program was then analyzed to determine its strengths, weaknesses, opportunities and threats (SWOT) based on previous practical experience in civil engineering, along with previous programs and results obtained from literature studies. The SWOT analysis was proceeded by a validation process by distributing questionnaires to stakeholders. Stakeholders consisted of program executors, namely construction companies and targeted participants, namely high school students. Questionnaires were distributed to assess whether the program was considered interesting, acceptable and feasible according to potential executors and participants. Conclusions regarding the validity of the proposed program were then drawn based on the results of the survey of respondents. The flowchart of the research methodology can be viewed in Figure 2. 


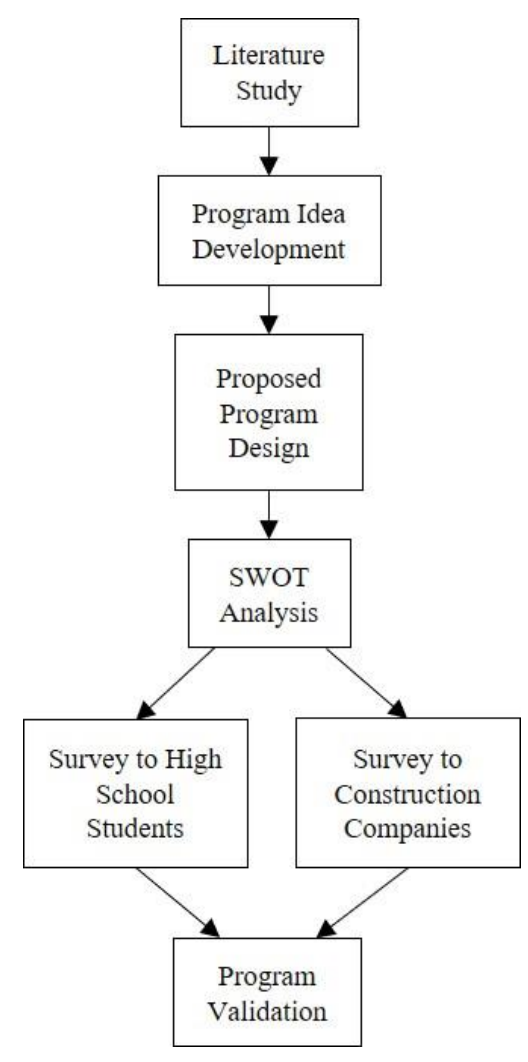

Figure 2. Methodology Flowchart

\section{Results and Discussions}

\subsection{Proposed CSR Program: Using Miniature Houses as Learning Tools}

The proposed CSR program in this study is an educational, project-based program. The program is a workshop on individual house construction with miniature houses built using construction materials, like the one demonstrated by Ouroboros Arq, as both a learning tool and project material [13]. Since the aim of the program is to increase society's interest and knowledge of engineering, as well as increase the number of potential engineers, the program is aimed for high school students.

The workshop is planned to be conducted over the course of 2 days. The main activities of this educational program are presentations and demonstrations, followed by practical applications by the participants. The material to be presented is construction materials and stages of individual houses as the basis of this program. The presentation will then be followed by a demonstration of construction techniques using miniature houses. Finally, the participants are going to be given the opportunity to work on building the miniature house themselves. The workshop outline plan is detailed in Table 1 .

Due to time constraints, it is not possible to demonstrate the entire process of building the miniature house from beginning to end. However, applicable construction practices for each stage can still be demonstrated and practiced by preparing several miniature models for each construction stage. That way, even though the model is not built completely, participants can still gain experience in working on each building stage.

\subsection{SWOT Analysis of Proposed CSR Program}

The proposed CSR workshop was assessed to identify internal and external factors of its execution. The SWOT (strengths, weaknesses, opportunities, threats) analysis was used to evaluate its potentials, as well as to anticipate challenges. Considerations used in this analysis are obtained mostly from previous CSR programs, their limitations and results, as well as other practical experience in civil engineering. The workshop's SWOT analysis matrix is presented in Table 2.

\subsection{Validation of Proposed CSR Program by Stakeholders}

After being assessed in a SWOT analysis, the proposed program was validated based on the responses of potential stakeholders, namely engineers in construction companies and high school students. The distributed questionnaires aim to obtain information about the interests of stakeholders in the proposed program, along with assessments on the implementation of the program and its feasibility. The information obtained was also used to confirm the previously conducted SWOT analysis.

\subsubsection{Validation by Construction Companies}

The validation process was directed towards engineers working in the construction sector, such as structural engineers, architects, and contractors. This validation process was conducted to test whether the program is considered feasible and interesting to be executed by engineers in construction companies. As the survey was conducted, 31 responses were obtained. The respondents' demographic distribution based on their construction company types is presented in Figure 3.

Survey results from construction companies on the proposed workshop program as displayed on

Table 3, Figure 4 and Figure 5 can be summarized as follows:

- $94 \%$ had never participated in and $90 \%$ had never organized similar programs.

- $74 \%$ were interested in organizing the workshop.

- $\quad 97 \%$ considered the program to be feasible and capable of accomplishing its goal to increase high school students' interest in engineering

- $45 \%$ suggested the program's duration to be two days, considering the sequence of activities to be done

\section{Respondents' Construction Company Types}

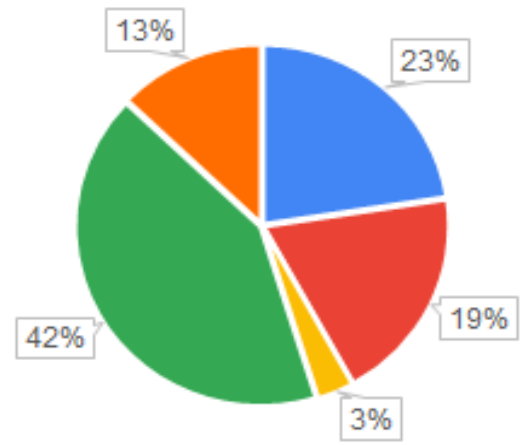

- Structural Engineering

- Architecture

- Construction

Management

- Contractor

- Developer

Figure 3. Demographic Distribution of Respondents' Construction Company Types 
Table 1. Workshop Outline Plan

\begin{tabular}{|c|c|c|c|}
\hline No. & Workshop & Description & Aims \\
\hline \multicolumn{4}{|c|}{ Material Presentation Session } \\
\hline 1. & $\begin{array}{l}\text { Construction Materials and } \\
\text { Stages of Simple Individual } \\
\text { Houses }\end{array}$ & $\begin{array}{l}\text { This session explains the materials } \\
\text { (concrete and steel rebars) and equipment } \\
\text { used along with the construction process } \\
\text { of an individual house. }\end{array}$ & $\begin{array}{l}\text { - Participants learn the construction materials and their } \\
\text { usage on a building project } \\
\text { - Participants learn the construction stages and } \\
\text { sequences of an individual house project, as well as the } \\
\text { required elements of each stage }\end{array}$ \\
\hline \multicolumn{4}{|c|}{ Breakout Sessions (Demonstration and Practical Application) } \\
\hline 1. & $\begin{array}{l}\text { Stage 1: Land Preparation and } \\
\text { Excavation Works }\end{array}$ & $\begin{array}{l}\text { Stage } 1 \text { demonstrates and practices the } \\
\text { process of "land" (the work area) } \\
\text { preparation, marking, making the layout } \\
\text { and excavation according to building } \\
\text { plans. }\end{array}$ & $\begin{array}{l}\text { - Participants learn the preliminary/ preparation process, } \\
\text { starting from collecting engineering drawings, } \\
\text { followed by land preparation and making the layout } \\
\text { - Participants learn how to apply layouts on drawing to } \\
\text { the site area through the process of } \\
\text { landmarking/staking and setting building lines } \\
\text { - Participants learn the process of excavation according } \\
\text { to the land markings/stakes prepared earlier. }\end{array}$ \\
\hline 2. & $\begin{array}{l}\text { Stage 2: Foundation, Column an } \\
\text { Stair Works }\end{array}$ & $\begin{array}{l}\text { d Stages } 2 \text { and } 3 \text { demonstrate and practice } \\
\text { concrete reinforcing and casting of }\end{array}$ & - Participants learn the process of forming concrete \\
\hline 3. & $\begin{array}{l}\text { Stage 3: Beam and Floor Slab } \\
\text { Works }\end{array}$ & $\begin{array}{l}\text { structural elements, namely foundations, } \\
\text { columns, beams, slabs and stairs. These } \\
\text { sessions also show the equipment and } \\
\text { technique used in the construction of those } \\
\text { structural elements. }\end{array}$ & $\begin{array}{l}\text { - Participants learn the process of making and casting } \\
\text { concrete for each structural element } \\
\text { Participants learn the tools and materials, such as } \\
\text { wires/ties and plywood formworks, necessary in } \\
\text { concrete works }\end{array}$ \\
\hline 4. & Stage 4: Brick Wall Works & $\begin{array}{l}\text { Stage } 4 \text { demonstrates and practices the } \\
\text { building of brick walls }\end{array}$ & $\begin{array}{l}\text { - Participants learn the process of arranging and building } \\
\text { brick walls, along with the necessary tools and } \\
\text { materials }\end{array}$ \\
\hline 5. & Stage 5: Roofing Works & $\begin{array}{l}\text { Stage } 5 \text { demonstrates and practices the } \\
\text { framing and installation of roofs and roof } \\
\text { coverings }\end{array}$ & $\begin{array}{l}\text { - Participants learn the construction of roof } \\
\text { frames/trusses, the variety of frame materials and their } \\
\text { building techniques } \\
\text { - Participants learn the variety of roof coverings and } \\
\text { their installations }\end{array}$ \\
\hline 6. & Stage 6: Finishing Works & $\begin{array}{l}\text { Stage } 6 \text { demonstrates and practices } \\
\text { finishing works of walls (plastering) and } \\
\text { floors (tiling) }\end{array}$ & $\begin{array}{l}\text { - Participants learn the materials, procedures, and } \\
\text { variety of wall finishes } \\
\text { - Participants learn the methods and guides used in } \\
\text { making the layout and installing floor tiles }\end{array}$ \\
\hline
\end{tabular}

Table 2. Workshop SWOT Analysis Matrix

\begin{tabular}{|c|c|}
\hline Strengths (S) & Weaknesses (W) \\
\hline $\begin{array}{l}\text { - Demonstration tool: The usage of miniature houses built with } \\
\text { construction materials provides a more detailed visualization of } \\
\text { building materials and construction. } \\
\text { - Appeal: Demonstrations and practical applications of construction } \\
\text { procedures offer a greater impression to potential participants } \\
\text { compared to a regular presentation } \\
\text { - Human resources: Construction companies have the human } \\
\text { resources needed to perform and teach construction techniques of } \\
\text { individual houses. }\end{array}$ & $\begin{array}{l}\text { Duration: The sequence of demonstrations and practical } \\
\text { applications for every construction stage is very time-consuming. } \\
\text { Due to time constraints, interactive activities become very limited. } \\
\text { - Cost: In order to conduct demonstrations for each construction } \\
\text { stage, multiple miniature houses are required. Building multiple } \\
\text { miniature houses out of construction materials requires a relatively } \\
\text { huge cost. }\end{array}$ \\
\hline Opportunities $(\mathrm{O})$ & Threats $(\mathrm{T})$ \\
\hline $\begin{array}{l}\text { - Uniqueness: Workshops involving participants in projects, namely } \\
\text { building miniature houses, is not common yet and thus, can be } \\
\text { appealing to potential participants. } \\
\text { - Partnership opportunities: Building miniature houses using } \\
\text { construction materials can be an opportunity for construction } \\
\text { companies to partner with material suppliers in the execution of the } \\
\text { program. } \\
\text { - Potential: Should this program be successfully executed, } \\
\text { impressions of engineering fields among students will improve, } \\
\text { creating opportunities for other programs }\end{array}$ & $\begin{array}{l}\text { - Participants' perception: Workshops related to engineering may be } \\
\text { considered uninteresting due to the perception of engineering being } \\
\text { complicated and boring. The number of students willing to } \\
\text { participate may not be great. } \\
\text { - Participants' time availability: Given that this kind of program is } \\
\text { still uncommon, the amount of time that students are willing to } \\
\text { spare will be limited. As a result, the demonstration and coaching } \\
\text { process would not be as ideal as originally aimed. }\end{array}$ \\
\hline
\end{tabular}


Table 3. Construction Companies Survey Questions on the Workshop

\begin{tabular}{ll}
\hline No. & \multicolumn{1}{c}{ Survey Questions } \\
\hline Q1 & Have you ever participated in a similar program? \\
Q2 & Have you ever been involved in organizing a similar \\
& program? \\
Q3 & Are you interested in organizing the workshop? \\
Q4 & Do you consider the workshop feasible and applicable? \\
Q5 & Do you consider the workshop able to increase high school \\
& students' interest in engineering? \\
\hline
\end{tabular}

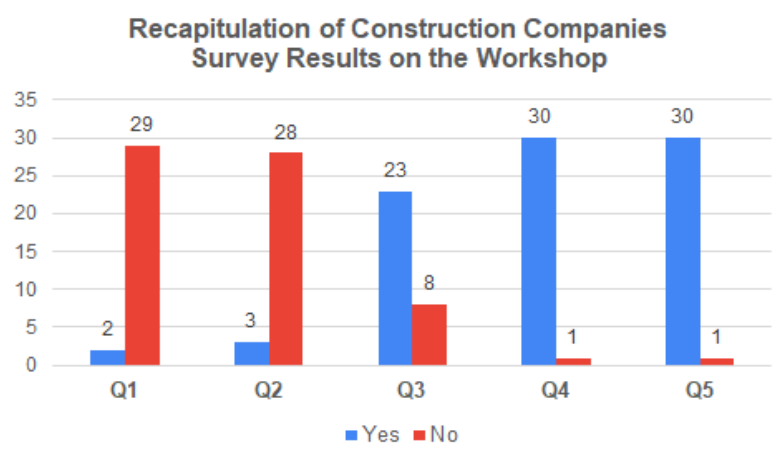

Figure 4. Construction Companies Survey Results on the Workshop

\section{Recommended Duration of Workshop}
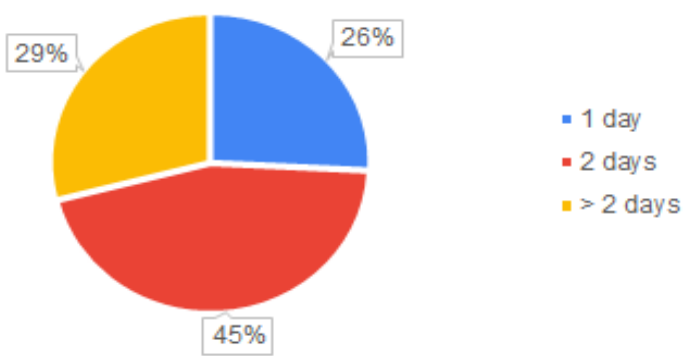

Figure 5. Construction Companies Survey Results on the Workshop's Duration

Several critics and suggestions from construction company respondents are as follows:

- The program can be targeted to students of other educational backgrounds, for example, vocational high school (SMK) and university students who are undergoing studies in construction

- The program can be developed to introduce structures apart from individual houses, including more interesting structures like bridges to interest students further

- There need to be further considerations on the costs required to execute the program

Based on the survey results, it can be seen that similar programs have not been commonly conducted. In accordance to the results of the SWOT analysis, this workshop has the potential to have a unique appeal, including to potential organizers. This is proved by having a majority of respondents expressing interest in participating. The program is also considered to be able to achieve the goal of increasing interest and knowledge in the field of engineering. However, although the overall program is feasible, time and cost constraints will need to be taken into consideration in the planning and organizing process.

\subsubsection{Validation by High School Students}

The validation process was also directed towards prospective participants, namely high school students. This validation process was conducted to test whether the program is considered interesting and preferrable by students as targeted participants. With regards to the program's objective of increasing interest and knowledge, a survey was also conducted to determine whether or not the respondents were interested and knowledgeable about the field of civil engineering. As the survey was conducted, 32 responses were obtained.

Preliminary survey results on interest and knowledge of civil engineering as presented on Table 4, Figure 6 and Figure 7 are as follows:

- $75 \%$ do not show interest in engineering. Out of the remaining $25 \%$, no one shows interest in pursuing studies in the field of civil engineering

- $69 \%$ know what civil engineering is. Keywords often used to describe the field are "design", "build", "buildings" and "construction".

- Information on the field of civil engineering is mostly obtained from the internet/social media (37\%), followed by associates/friends/family members (29\%). Only $15 \%$ obtain such information from educational institutes and none from government socializations or construction companies.

Table 4. High School Students Survey Questions on Interests in Engineering

No. Survey Questions

Q2 Do you have any interest in pursuing studies on civil engineering?

Q3 Do you know anything about civil engineering?

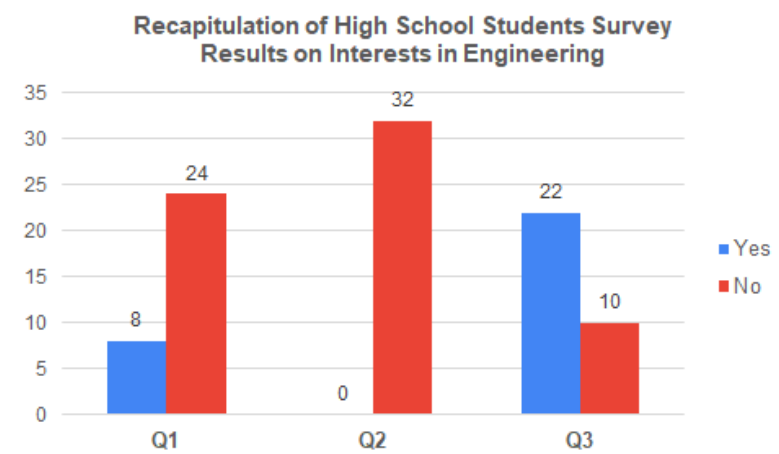

Figure 6. High School Students Survey Results on Interests in Engineering

Students' References on Civil Engineering

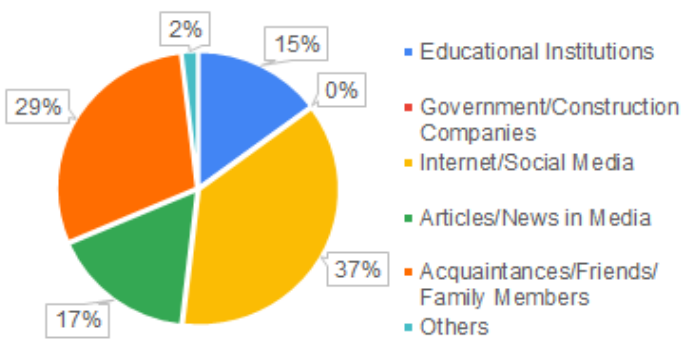

Figure 7. High School Students Survey Results on References on Civil Engineering 
Survey results from high school students on the proposed workshop program as displayed on Table 5, Figure 8 and Figure 9 can be summarized as follows:

- Only one (3\%) respondent had participated in a similar program.

- $84 \%$ considered the proposed workshop program to be interesting, but only $50 \%$ showed interest in participating. Curiously, 38\% showed interest in participating, although not having any interest in engineering.

- $41 \%$ suggested the program's duration to be two days, considering the sequence of activities to be done

Table 5. High School Students Survey Questions on the Workshop

\begin{tabular}{ll}
\hline No. & \multicolumn{1}{c}{ Survey Questions } \\
\hline Q1 & Have you ever participated in a similar program? \\
Q2 & Do you consider the workshop interesting? \\
Q3 & Are you interested in participating in the workshop? \\
\hline
\end{tabular}

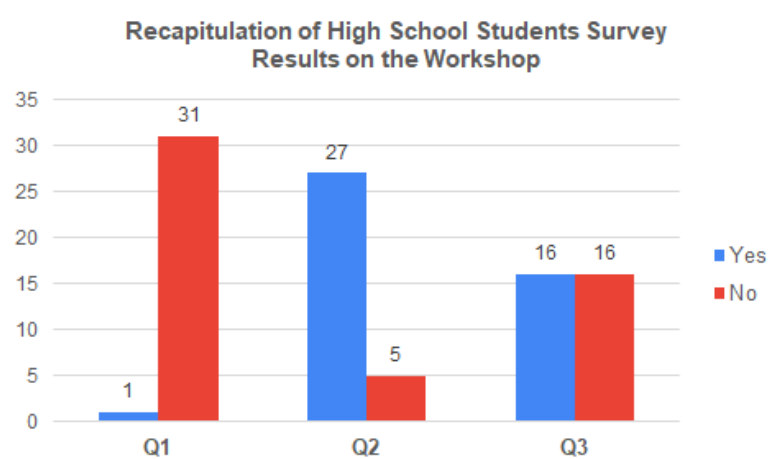

Figure 8. High School Students Survey Results on the Workshop

\section{Recommended Duration of Workshop}

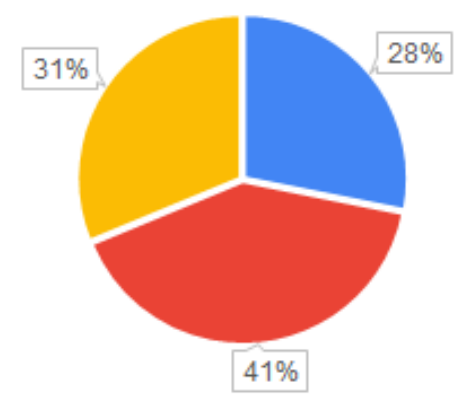

.1 day

- 2 days

" $>2$ days

Figure 9. High School Students Survey Results on the Workshop's Duration

Based on the survey results, it can be seen that among high school students, similar programs were also still not common. So, the workshop can attract potential participants. However, while a majority of respondents found this program appealing, only half of them were interested in joining. On the other hand, while most were not interested in engineering, many still found this program appealing and were interested in participating. From both findings, it can be seen that there are opportunities and challenges at the same time regarding the perceptions and interests of potential participants in this program, just as formulated in the SWOT analysis.

\section{Conclusions}

Based on the program's formulation, SWOT analysis, and validation by stakeholders, the following conclusions can be drawn about the proposed workshop program and the usage of miniature houses built with construction materials:

- Similar programs are still uncommon among both potential organizers (construction companies) and potential participants (high school students). Therefore, the workshop has the potential as a unique program moreover since a majority of respondents are interested in both conducting and participating in the program.

- The workshop's execution is reasonable and feasible, but it has constraints with regard to time and cost. So, in its organizing process, further consideration is required on the sequence of activities and durations, as well as the number and usage of miniature houses as learning tools.

- Students' interest in the field of civil engineering is still low, and the contribution of construction companies in increasing it has not been significant either. Even so, judging by the responses of both construction companies and high school students, the program can fulfill the goal of increasing interest in and knowledge of civil engineering.

The workshop itself still has room for improvement, including:

- Program adjustments to accommodate different participant groups, for instance, vocational high school (SMK) or engineering students who have received education in the field. In this case, the focus of the program is not only set on increasing participants' interest but also providing structured technical knowledge on construction.

- Students can utilize a variation of building and construction types apart from individual houses in the learning process. More complex constructions, such as high-rise buildings or bridges, may be considered more challenging and interesting by potential participants. However, factors such as cost, time and facilitators' competence in coaching students on those constructions should still be taken into consideration.

\section{References}

[1]. Wahyudi, I. (2019, January 10). Jumlah insinyur di Indonesia masih sedikit. AntaraNews Sumatera Barat. Retrieved October 15, 2020, from https://sumbar.antaranews. com

[2]. Simorangkir, E. (2019, April 12). Potret Miris SDM RI: Minim Insinyur dan Kerja Tak Sesuai Bidang. Detik Finance. Retrieved October 15, 2020, from https://finance.detik.com/berita-ekonomi-bisnis

[3]. Mutiara, P. (2016, August 19). Indonesia Kekurangan 80\% Insinyur Profesional. Media Indonesia. Retrieved October 15, 2020, from https://mediaindonesia.com

[4]. Indonesia. 2014. Undang-Undang No. 11 Tahun 2014 tentang Keinsinyuran. Lembaran Negara Republik Indonesia Tahun 2014 No. 6. Jakarta: Sekretariat Negara.

[5]. Mismatches, and Future Directions TRIPATRA Dukung Peningkatan SDM Unggul Bidang Engineering. (2019, October 14). Tripatra News. Retrieved October 23, 2020, from https://www.tripatra.com/en/information/news/ 
tripatra-engineering-camp-memperkenalkan-teknikkepada-siswa-sekolah-menengah-pertama

[6]. Smith, J.M. and Lucena, J.C. (2018). "Social Responsibility in Engineering Education and Practice: Alignments." ASEE Annual Conference \& Exposition.

[7]. Woods, J., Mazur, N., and Gales, J. (2017). "Teaching The Fundamentals of Civil Engineering Materials Through Experiential Learning." Proc. 2017 Canadian Engineering Education Association (CEEA17).

[8]. Jordaan, M. (2014). "Community-based Project Module: A service-learning module for the Faculty of Engineering, Built Environment and Information Technology at the University of Pretoria." International Journal for Service Learning in Engineering. Special Edition, pp. 269-282, Fall 2014.

[9]. Coyle, E. J., Jameson, L. H., and Oakes, W. C. (2005) "EPICS: Engineering Projects in Community Service." International Journal of Engineering Education. Vol. 21, No. 1, pp. 139-150.

[10]. Glade, S., Karter, C., and Pagilla, K. (2014). "Case Studies from a Community-Focused Engineering Program with
Projects in Haiti and Nicaragua." International Journal for Service Learning in Engineering. Special Edition, pp. 551-562, Fall 2014.

[11].Farinde, A. A., Tempest, B., and Merriweater, L. (2014). "Service Learning: A Bridge to Engineering for Underrepresented Minorities." International Journal for Service Learning in Engineering. Special Edition, pp. 475-491, Fall 2014.

[12].Goodyer, J. and Soysa, I. (2017). "A New Zealand National Outreach Program - Inspiring Young Girls in Humanitarian Engineering". International Journal for Service Learning in Engineering, Humanitarian Engineering and Social Entrepreneurship. Vol. 12, No. 2, pp. 1-14.

[13].Ibáñez, Á. (2019, November 15). The Fascinating Charm of Miniature Houses Built with "Real" Techniques. Ferrovvial Blog. Retrieved November 01, 2020, from https://blog.ferrovial.com/en

[14].Souza, E. (2020, October 06). Miniature Construction: Modeling from Structure to Finish. ArchDaily. Retrieved November 01, 2020, from https://www.archdaily.com/ 